\title{
EFFECT OF THE T-DOMAIN ON INTRACELLULAR TRANSPORT OF DIPHTHERIA TOXIN
}

\author{
A. J. LABYNTSEV, D. V. KOLYBO, E. S. YURCHENKO, A. A. KABERNIUK, \\ N. V. KOROTKEVYCH, S. V. KOMISARENKO
}

Palladin Institute of Biochemistry, National Academy of Sciences of Ukraine, Kyiv; e-mail: lab.andrey@gmail.com

Subunit B of diphtheria toxin (DT), which consists of two domains: $R$ (receptor-binding) and $T$ (transmembrane), plays an important role in toxin-receptor binding on the cell-targets and in transportation of catalytic subunit $A$ to the cell cytosol. Recombinant analogues of the subunit B are promising representatives in the unique class of transporting proteins, able to deliver different types of biologically active molecules to cell cytosol. In the development of these protein constructs understanding of the role of each of the DT fragments in determination of transporting pathways of endocytosed complex toxin-receptor is urgently required.

We have studied in this work the T-domain effect on intracellular transport of recombinant fragments of DT. We have compared intracellular transport of the R-domain and the subunit $B$, the last one consisted of both R-domain and T-domain. Recombinant fragments of DT used in this work were labeled with fluorescent proteins, which allowed applying colocalization technique for our study. Application of confocal microscopy technique revealed differences in transportation of recombinant derivates of DT in Vero cells: $R$-domain moved faster than subunit B to tubular compartments. Analysis of R-domain and subunit B transportation confirmed almost linear increase of their colocalization with the time regarding to Pearsons correlation coefficient (PCC). However, amount of colocalized with R-domain subunit B were not linearly increased with time according to Manders coefficient $\left(M_{1}\right)$, this could indicate the ability of subunit $B$ to transport to such compartments that $R$-domain do not reach. Possible role of the $T$-domain in intracellular transportation and compartmentalization of the toxin may be associated with the ability of the T-domain to form a proton channels and its ability to interact with COPI complex.

Key words: diphtheria toxin, T-domain of diphtheria toxin, endocytosis, fuorescent proteins, confocal microscopy, intracellular transport.

$\mathrm{D}$ iphtheria toxin (DT) is a major virulence factor of the diphtheria causative agent bacteria Corynebacterium diphtheriae. DT belongs to the family of bacterial AB toxins, featured by existence in their structure of two functionally distinct subunits of subunit A (Enzymatically Active) and subunit B (Receptor Binding). Subunit B (SubB) is responsible for binding with membraneanchored receptor and participates in a translocation of subunit A (SubA) into cell cytosol. Subunit A is ADP-ribosyltransferase, which modifies intracellular target - eukaryotic translation elongation factor 2 (eEF-2). Accumulation of the large amount of modified eEF-2 leads to termination of protein biosynthesis and further cell death. Detailed scheme of toxin action was covered in reviews [1,2].

DT is made by one polypeptide chain, but to reach cytotoxic activity proteolytic cleavage of the toxin into separate fragments (subunits) is necessary. DT subunits are connected by polypeptide linker, which cleavages by membrane-anchored proteinase from the serine endoproteases family furin. It is known that other proteinases [3], like proteinase PACE4 $[4,5]$, may activate DT. Furin make DT active by cleavage of polypeptide bond between residues of Arg193 and Ser194 in a loop region consisting of 14 amino acid residues, after DT subunits are linked only by disulfide bond between cysteine 186 and $201[6,7]$. Its reduction takes place in cytosol with assistance of thioredoxin reductase [8].

Tertiary structure of DT is formed by three domains, each of which has specific structure and function. N-terminal catalytic $\mathrm{C}$-domain made by amino acid residues 1-193, corresponds to subunit A (21.1 kDa). Subunit B (37.2 kDa) consists of transmembrane T-domain (Td) formed by amino acid 
residues 205-378 and of C-terminal receptor-binding R-domain (Rd), formed by residues 386-535 [9]. Tdomain possesses hydrophobic properties and have high content of spiral structures, it is responsible for DT-endosomal membrane interaction and for translocation of subunit A into the cell cytosol [9]. R-domain of subunit B possesses hydrophilic properties and have high affinity for trans-membrane form of proHB-EGF (progenitor of Heparin-Binding Epidermal Growth Factor-like Growth Factor) [10-13].

DT-sensitive cells have on their surface from 4000 to 200000 proHB-EGF molecules per cell [14]. DT transports into the cell through endosomes, which formed via clathrin-dependent receptormediated endocytosis [15]. DT changes its conformation after acidification of endosome lumen, hydrophobic domains become exponated outside the molecule and, correspondently, binding of the toxin with the membrane lipids increases, that may cause SubA translocation into the cell cytosol. Reduction of disulfide bound between subunits takes place in the cytosol and it causes release of SubA and development of its catalytic activity.

SubA translocation throughout endosome lipid bilayer is mediated by the T-domain [16, 17]. But DT receptor proHB-EGF and the R-domain, possibly, participates in this process as well [18-20]. Few regions of the R-domain (380-421, 422-441 i 442-483) plunge deeply into the membrane, this process is accompanied by formation of $\alpha$-spiral transmembrane structure [20]. One of those three regions (442-483) possesses phosphate-binding P-site (456-458-460472-474) [21], which, possibly, plays some role in the process of translocation.

Transmembrane domain consists of 9 helixes, gathered in 3 layers. The first layer is created by 2 hydrophobic C-terminal helixes TH8 and TH9, second layer was created by 3 hydrophobic helixes TH5-TH7, and the third one is created by 4 helixes TH1-TH4, which possess strong hydrophilic features. Helixes TH8-TH9, which are bound by loop TL5, create the nucleus of the domain and participate in subunit A translocation into cytosol [9]. It is known that $\mathrm{Td}$ is able to interact with proteins which have intrinsically disordered structure and are in the condition of "molten globule" [22]. One of the conditions of successful recognition of protein by $\mathrm{Td}$ is its mild hydrophobicity. Thus, $\mathrm{Td}$ in the process of translocation shows properties similar to chaperon proteins [23].

Despite detailed mechanism of SubA translocation is not clearly known, the major requirement for successful translocation is acidification of endosome lumen what causes conformation changes in the toxin molecule. It is known that both DT subunits plunge into the membrane, though SubA plunges less deep and its groups less exponated to lipids due to contact with SubB, which partially covers SubA and prohibits its contact with membrane lipids [24].

That is why further detailed study of mechanisms of SubA translocation into cytosol and mechanisms of resistance to DT needs new experimental models and new instruments for research of these processes. One of such instruments may be fluorescent truncated DT analogues, in particular, its SubB and R-domain, fused with different fluorescent proteins, for example, with red fluorescent protein mCherry and with green fluorescent protein EGFP [25]. Thus, the aim of this work is to investigate features of transportation of subunit B of diphtheria toxin and its R-domain on cell line Vero with recombinant fluorescent truncated DT forms $\mathrm{mCh}$-SubB and EGFP-Rd.

\section{Materials and Methods}

Recombinant proteins expression. Recombinant proteins EGFP, mCherry, mCh-SubB and EGFP-Rd have been obtained from Escherichia coli BL 21 (DE3) Rosetta (Novagen, USA) host strain, transformed by genetic constructions based on plasmid vector $\mathrm{pET}-24 \mathrm{a}(+)$ (Novagen, USA).

Bacterial culture has been grown at $37{ }^{\circ} \mathrm{C}$ under aeration conditions $(250 \mathrm{rpm})$ up to $\mathrm{A}_{600}-0.5$ 0.7 in the $2 x Y T$ medium with $50 \mathrm{mg} / 1$ of kanamycin and $170 \mathrm{mg} / \mathrm{l}$ of chloramphenicol. Expression of the proteins has been inducted by the addition of $1 \mathrm{mM}$ isopropyl $\beta$-D-1-thiogalactopyranoside (IPTG). Target proteins expression has been performed during 3 hours at $30{ }^{\circ} \mathrm{C}$ under strong aeration conditions (250 rpm), after what cells have been precipitated by centrifugation at $3300 \mathrm{~g}$ during $10 \mathrm{~min}$.

Purification of recombinant proteins with metal-affinity chromatography on $\mathrm{Ni}^{2+}$-NTA-agarose. Recombinant proteins has been purified with metalaffinity chromatography on the column with $\mathrm{Ni}^{2+}$ NTA-agarose. Column containing affine sorbent has been equilibrated with buffer $\mathrm{E}\left(50 \mathrm{mM} \mathrm{Na} \mathrm{HPO}_{4}\right.$, $0.5 \mathrm{M} \mathrm{NaCl}, 10 \mathrm{mM}$ imidazole, $\mathrm{pH} 8.0$ ) with $8 \mathrm{M}$ of urea. Centrifuged bacterial cells have been resuspended in buffer E containing $8 \mathrm{M}$ urea $(1 \mathrm{ml}$ of buffer solution per $10 \mathrm{ml}$ of cell culture). Next, samples have been sonicated by ultrasonic homogenizer LabsonicM (Sartorius, Germany). Cell residues have 
been precipitated by centrifugation under $10000 \mathrm{~g}$ $15 \mathrm{~min}$, and a column has been filled by supernatant.

Renaturation by washing the column with gradational decrease of urea concentration $(8 \mathrm{M} \rightarrow 6 \mathrm{M}$ $\rightarrow 4 \mathrm{M} \rightarrow 2 \mathrm{M} \rightarrow 0 \mathrm{M}$ ) in buffer $\mathrm{E}$ has been performed for obtaining soluble recombinant proteins. Protein was eluted by buffer E containing $400 \mathrm{mM}$ imidazole. Protein for further procedures was dialyzed against PBS $(0.14 \mathrm{M} \mathrm{NaCl}, 0.03 \mathrm{M} \mathrm{KCl}$, $0.011 \mathrm{M} \mathrm{Na}_{2} \mathrm{HPO}_{4}, 0.002 \mathrm{M} \mathrm{KH}_{2} \mathrm{PO}_{4}, \mathrm{pH}$ 7.2).

Electrophoretic separation of proteins. Electrophoresis in polyacrylamide gel with SDS has been performed in compliance with modified methodology of Schagger H. [26].

Cultivation of Vero cell line. Vero cell line, originating from green monkey kidney epithelium (Cercopithecus aethiops) [27], was obtained from the cell lines bank of the R.E. Kavetskiy Experimental Pathology, Oncology and Radiobiology Institute of NAS of Ukraine. Vero cell line has been cultivated on the nutrient medium RPMI-1640 containing L-glutamine, with addition of 5\% FCS (fetal calf serum), streptomycin (100 mg/l), penicillin (10 $000 \mathrm{U})$ and amphotericin B $(250 \mu \mathrm{g} / \mathrm{l})$ under conditions of increased concentration of $\mathrm{CO}_{2}$ in atmosphere.

Flow cytometry. Cells have been detached from flask by addition of $20 \mathrm{mM}$ EDTA in PBS. Optimal quantity of cells for staining was $0.3-0.5 \times 10^{6}$ per probe. Cells have been stained by incubation with $725 \mathrm{nM}$ of proteins in $200 \mu \mathrm{l}$ of BSA/PBS solution ( $1 \%$ BSA in PBS) for $15 \mathrm{~min}$ at $4{ }^{\circ} \mathrm{C}$.

For washing of non-bound proteins, $1 \mathrm{ml}$ of BSA/PBS was added, and then cell pellet carefully resuspended and centrifuged (200-300 g, 10min). Next, cell pellet was resuspended in $1 \mathrm{ml}$ of BSA/ PBS. Further solution of stained cells were transferred into the test-tubes for cytometer.

Determination of cells fluorescence intensity were performed on flow cytometer Coulter Epics XL (Beckman Coulter, USA). There are parameters beneath, used in the protocol: forward light scatter (FS), side light scatter (SS) and logarithm of the fluorescence level on channel FL1 (515-535 nm) for probes stained with EGFP and channel FL3 $(610-630 \mathrm{~nm})$ for probes stained with mCherry. Two graphs have been calculated with these parameters: dot plot of cells morphology (FS vs SS) and histogram of fluorescence intensity according to channel FL1 or FL3. Quantity of events per graph was 10000.

Preparation of cell specimens for confocal microscopy. Vero cells grew up on cover glass to semiconfluent state and then washed up by solution RPMI-1640 (pH 7.3). Fluorescent proteins in concentration of $145 \mathrm{nM}$ (EGFP-Rd) and $390 \mathrm{nM}$ (mChSubB) and $10 \mu \mathrm{M}$ of cell nuclei stain Hoechst 33342 in RPMI-1640 incubated at $37^{\circ} \mathrm{C}$ from 5 to $75 \mathrm{~min}$. Non bound proteins have been washed up by a solution RPMI-1640 after 15 min of incubation and only solution $10 \mu \mathrm{M}$ Hoechst 33342 in RPMI-1640 have been used for further incubation. After incubation cells were fixed by solution $4 \%$ of paraformaldehyde in $0.1 \mathrm{M}$ phosphate buffer during $40 \mathrm{~min}$ at $4{ }^{\circ} \mathrm{C}$. Cover glass with cells has been mounted on a slide in mounting medium based on polyvinyl alcohol

Cell specimens were analyzed on confocal microscope Zeiss LSM 510 Meta (Germany). Oil immersion objective Plan-Apochromat 63x/1.4 Oil DIC was used. EGFP chromophore was excited with $488 \mathrm{~nm}$ laser and chromophore mCherry chromophore was excited with $543 \mathrm{~nm}$ laser, information about fluorescence was collected on channels 505$530 \mathrm{~nm}$ for EGFP and 560-615 nm for mCherry. Nuclei stain Hoechst 33342 was excited with $405 \mathrm{~nm}$ laser and detected on 420-480 $\mathrm{nm}$ channel.

\section{Results and Discussions}

Obtaining of recombinant fluorescent proteins. Genes, which encode fused proteins mCherry - subunit B DT and R-domain DT - EGFP (mCh-SubB and EGFP-Rd) was created by merging of corresponding nucleotide sequences into one readin frame [25]. Protein expression was performed in the culture E. coli BL 21 (DE3) Rosetta (Novagen, USA), transformed by pET-24a(+)-based (Novagen, USA) genetic constructs. Purification of recombinant proteins EGFP, mCherry, mCh-SubB and EGFP$\mathrm{Rd}$ performed with metal affinity chromatography on $\mathrm{Ni}^{2+}$-NTI column. Taking into the account that products of interest were insoluble, procedure of refolding was performed. Analysis of protein fractions after the refolding was performed on $12 \%$ PAAGE. (Fig. 1).

Flow cytometry. Determination of ability of fluorescent DT fragments mCh-SubB and EGFP$\mathrm{Rd}$ to the specific interaction with cell DT receptor performed on Vero cells, on the surface of which proHB-EGF represented in considerable quantity (around $1-2 \times 10^{5}$ per cell).

Results of binding analysis presented in a histogram of fluorescence intensity distribution of Vero cells on channel FL1 (515-535 nm), which represents fluorescence EGFP, and on channel FL3 (610- 
$630 \mathrm{~nm}$ ), which represents fluorescence mCherry (Fig. 2). As that appears from the presented data, obtained fluorescent proteins $\mathrm{mCh}$-SubB and EGFPRd effectively bind to Vero cells in comparison with control proteins mCherry and EGFP, what indicates on specificity of fluorescent DT derivates interaction of with those sells.

To compare traffic of different DT derivates under condition of their simultaneous adding to Vero cells, molar ratio of these chimera proteins for their binding in equivalent quantity with cells needed to be determined first. To determine such ratio, Vero cells were stained with two proteins under condition that concentration of $\mathrm{mCh}$-SubB has been changed from 100 to $857.14 \mathrm{nM}$, but concentration of EGFPRd was constant $(500 \mathrm{nM})$. That is molar concentrations ratio of $\mathrm{mCh}-\mathrm{SubB}$ and EGFP-Rd changed in probes from $0.2: 1$ to $2: 1$.

EGFP-Rd and mCh-SubB binding with cells has been determined according to channels FL1 and FL3, correspondingly. Obtained results of fluorescence intensity of these cells is shown on dot plot (Fig. 3), where axis x demonstrates intensity of fluorescence on channel FL1 (EGFP-Rd fluorescence), and axis $y$ is intensity of fluorescence on channel FL3 (mCh-SubB fluorescence). Four regions are gated in the diagram with usage of corresponding control probes, which were stained with fluorescent proteins EGFP, mCherry, EGFP-Rd and $\mathrm{mCh}$-SubB. Gate A on the Fig. 3 (upper left dot plot). Gate A includes the unstained cells, according to channels FL1 and FL3 (double-negative staining), gate B includes the cells stained according to channel FL1, but not stained according to channel FL3, gate C gates cells, stained according to channel FL3, but not stained according to channel FL1, and gate D includes cells, stained according to both channels (double-positive staining).

Fluorescent signal from $\mathrm{mCh}-\mathrm{SubB}$ increased according to increase of concentration of this protein in the probe (Fig. 3). As mCh-SubB concentration increased, under stable EGFP-Rd concentration, fluorescence on channel FL1 slowly decreases, but stays in the gates $\mathrm{B}$ and $\mathrm{C}$, but intensity of fluorescence on channel FL3 gradually increases and transfers from negative gate $\mathrm{B}$ to a positive gate $\mathrm{C}$, what proves steady binding with cell receptors of both fluorescent DT derivates. In compliance with the experimental data, molar ratio of EGFP-Rd to mCh-SubB 1:2 was used in the next studies on confocal microscope. Best staining of cells by both DT fluorescent

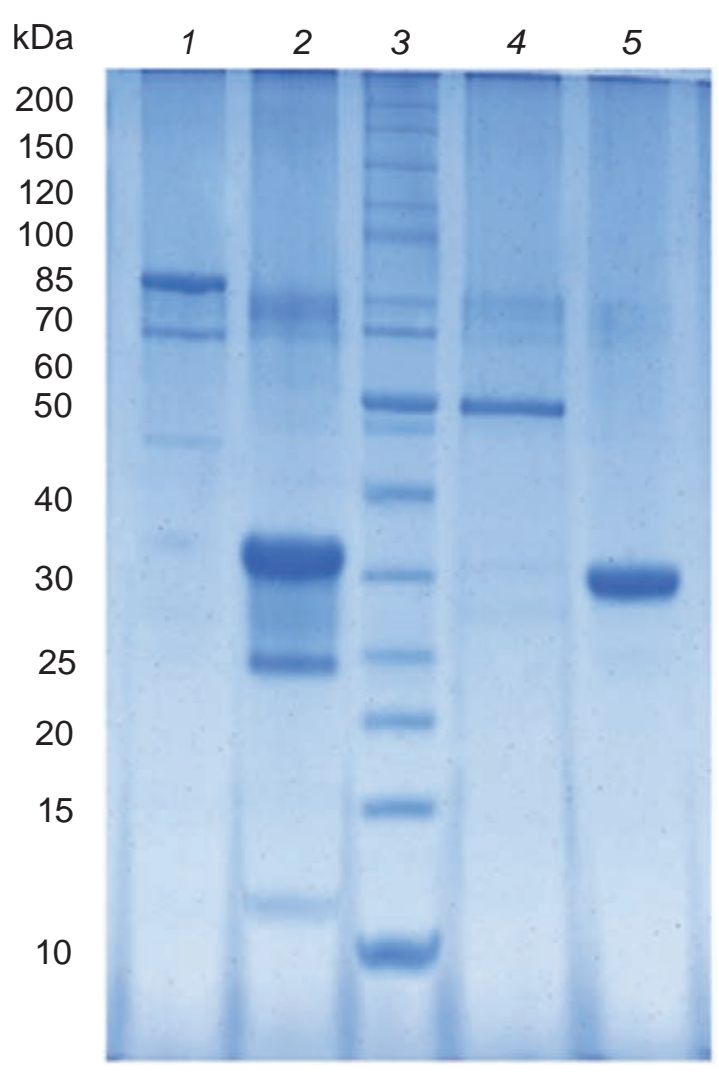

Fig. 1. Electroforegram of recombinant proteins $1-m C h-S u b B ; 2-m C h e r r y ; 3-$ molecular weight ladder; 4-EGFP-Rd; 5 - EGFP

derivates was observed under this ratio (Fig. 3, low right dot plot).

Confocal microscopy. Details of fluorescent DT derivates transport inside the cells were studied on Vero cell line. Cells were stained with proteins EGFP-Rd and $\mathrm{mCh}-\mathrm{SubB}$ in molar ratio $1: 2$. Colocalization between those proteins on the confocal images were detected with RG2B_Colocalization plugin for FIJI software [28].

As it appeared from Fig. 4, these proteins had different localization on the 15th minute of observation: $\mathrm{mCh}$-SubB located closer to the cell surface at the time when EGFP-Rd is localized closer to the cell nucleus; colocalization between these proteins was low. Similar state also observed on the 30th and 45th minutes of observation, however colocalization between them gradually increased. Both proteins started significantly colocalize only on the 60th min of observation, however EGFP-Rd has been situated already in tubular structures, at the time when $\mathrm{mCh}-\mathrm{SubB}$, predominantly, was situated in vesicular structures. $\mathrm{mCh}-\mathrm{SubB}$ and EGFP-Rd had a high level of colocalization in tubular struc- 




Fluorescence intensity on channel FL1, a.u.



Fig. 2. Comparative histograms of fluorescence intensity of Vero cells, which were stained with recombinant fluorescent proteins or unstained (control). A - Fluorescence intensity distribution of cells according to channel FL1 for control probe and probes, stained with EGFP and EGFP-Rd. B-Fluorescence intensity distribution of cells according to channel FL3 for control probe and probes, stained with $m$ Cherry and $m C h-S u b B$

tures on the 75th min of observation, however a part of mCh-SubB stayed not colocalized with EGFP$\mathrm{Rd}$. Thus, the obtained results point to possible DT T-domain influence on the intracellular toxin transport.

FIJI software with JACoP plugin was used for quantification analysis of colocalization between those proteins $[28,29]$. Obtained pictures were analyzed to calculate two parameters: Pearson correla- tion coefficient and Manders correlation coefficient (M coefficients) for mCh-SubB and EGFP-Rd. Pearson correlation coefficient (PCC) in this case shows probability that proteins $\mathrm{mCh}-\mathrm{SubB}$ and EGFP-Rd are colocalized, where meaning «0» corresponds with absence of colocalization, meaning «1» corresponds with full colocalization, and meaning «-1» means reverse dependency. 


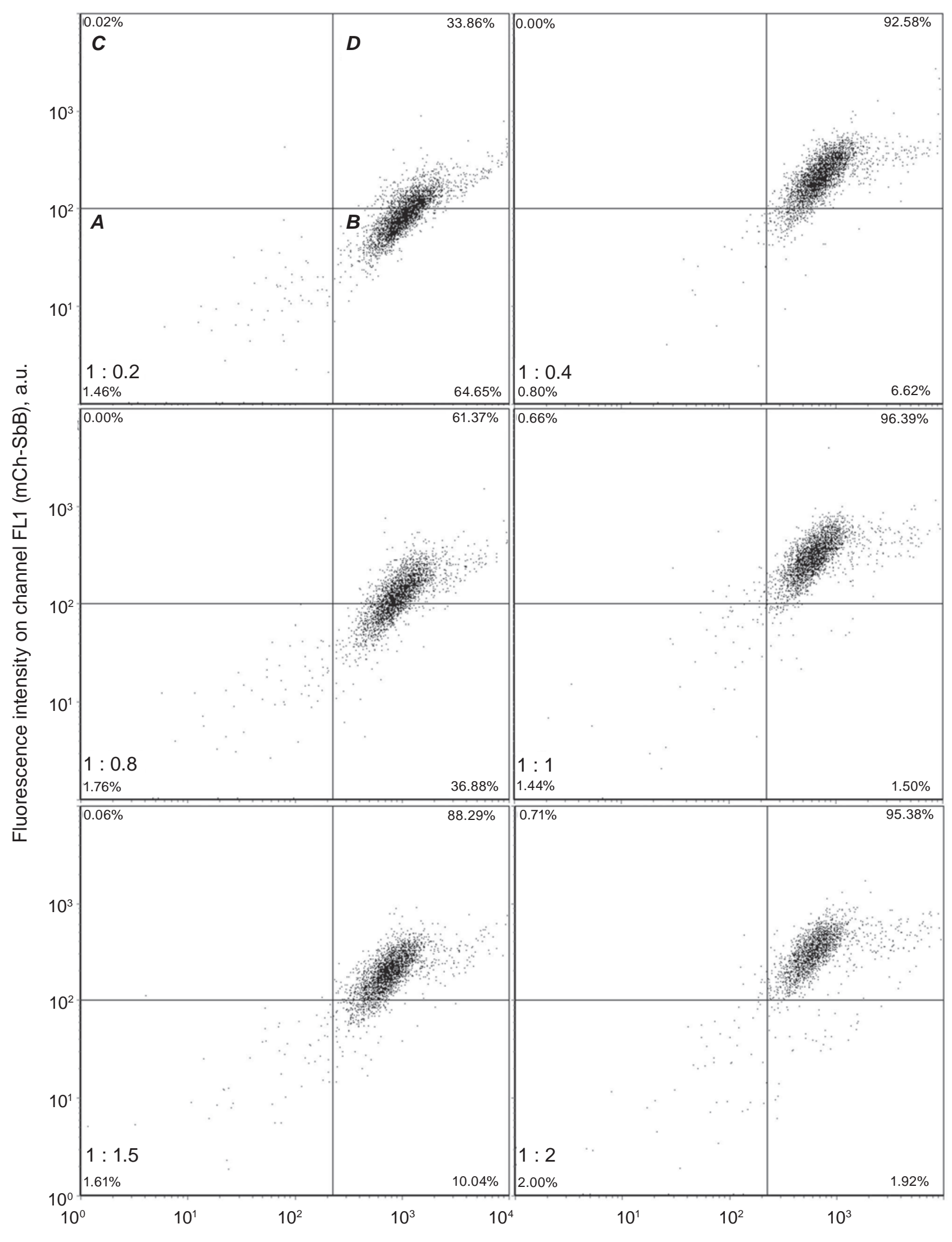

Fluorescence intensity on channel FL1 (EGFP-Rd), a.u.

Fig. 3. Comparing of cells fluorescence intensity according to channels FL1 and FL3, which were stained by recombinant proteins EGFP-Rd and $m C h-S u b B$ in molar ratio $1: 0.2 ; 1: 0.4 ; 1: 0.8 ; 1: 1 ; 1: 1.5$ and $1: 2$ 
PCC formula looks like this:

$$
P C C=\frac{\sum_{i}\left(R_{i}-\bar{R}\right)\left(G_{i}-\bar{G}\right)}{\sqrt{\sum_{i}\left(R_{i}-\bar{R}\right)^{2} \sum_{i}\left(G_{i}-\bar{G}\right)^{2}}},
$$

where $R_{i}$ and $G_{i}$ mean intensity of separate pixels $i$ on the picture according to channels of fluorescence $\mathrm{mCh}$-SubB and EGFP-Rd correspondently; $\bar{R}$ and $\bar{G}$ are average values of fluorescence intensity $\mathrm{mCh}-\mathrm{SubB}$ and EGFP-Rd on the whole picture.

Manders coefficients $M_{1}$ and $M_{2}$ show the percentage of protein of every color, colocalized with the studied partner of other color, corresponding with all quantity of protein of this color on the picture. In our case, coefficient $\mathrm{M}_{1}$ shows percentage SubB, colocalized with protein $\mathrm{Rd}$, and coefficient $\mathrm{M}_{2}$ shows percentage $\mathrm{Rd}$, colocalized with SubB correspondently. For example, meaning «1» of coefficient $M_{1}$ shows on this picture $100 \%$ of protein SubB colocalized with protein $\mathrm{Rd}$, but meaning «1» for $\mathrm{M}_{2}$ shows that $100 \%$ of $\mathrm{Rd}$ protein colocalized with protein SubB.

It is worth to note, that $\mathrm{M}_{1}$ points only to the portion of pixels of red colour (SubB), colocolized with pixels of green colour ( $\mathrm{Rd})$, and $\mathrm{M}_{2}$ point only to the portion of pixels of green colour (Rd), colocalzed with pixels of red colour (SubB): $M_{1}=\frac{\sum_{i} R_{i, \text { coloc }}}{\sum_{i} R_{i}}$ , where $R_{i, \text { coloc }}=R_{i}$ if signal from $G_{i}>0$, a $R_{i, \text { coloc }}$ $=0$ if signal from $G_{i}=0 ; M_{2}=\frac{\sum_{i} G_{i, \text { coloc }}}{\sum_{i} G_{i}}$, where $G_{i, \text { coloc }}=G_{i}$, if signal from $R_{i}>0$, and $G_{i, \text { coloc }}=0$, if signal from $R_{i}=0$. Meaning «0» means absence of colocalization between proteins. More detailed calculation and interpretation of the above-mentioned correlation coefficients we may learn from the publication Dunn et al. [30].

The calculated results of SubB and Rd colocalization are presented on the Fig. 5. As that appears from the graphs, relatively weak colocalization between SubB and Rd (PCC $=0.3-0.4$ for $5-45 \mathrm{~min}$ of study) was observed on the initial stages of those proteins internalization. Then colocalization between those two proteins increased and reached its maximum on the 75 th $\min$. $(\mathrm{PCC}=0.67)$, what correlates with the results of visual colocalization (Fig. 4). However, according to calculated Manders coefficients, SubB has a distinct dependency of colocalization on the time with Rd (coefficient $\mathrm{M}_{1}$ ), in comparison to dependency on colocalization of Rd with SubB (coefficient $\mathrm{M}_{2}$ ). Thus, coefficient $\mathrm{M}_{2}$ linearly increases within the entire observation time (5-75 $\mathrm{min}$ ) from 10 to $65 \%$. However, the coefficient $\mathrm{M}_{1}$ shows linear increase only from 5 th to 30 th min from 27 to $55 \%$, in the observation time 30-60 $\mathrm{min}$ it reaches plateau, and in an observation time from 60th to 75th $\mathrm{min}$ it shows a tendency to decrease from 55 to $45 \%$. According to Manders coefficients, such colocalization results may prove the ability of SubB from 30th to 60th min of investigation to transport through some compartment, in which the $\mathrm{Rd}$ goes as well. Correspondingly, the proteins may colocalize in this compartment, which was demonstrated with $\mathrm{M}_{2}$ and $\mathrm{PCC}$ increase and the results of visual colocalization (Fig. 4). However, different character of curves of $M_{2}$ and $M_{1}$ change in a time from 45 th till 75 th min of observation may point to the ability of SubB to be transferred to other compartments, which Rd does not reach within the studied period, and thus, the coefficient $\mathrm{M}_{1}$ from 45 th to 75th min has a tendency to decrease. Moreover, not colocalized with Rd part of SubB can be seen on Fig. 4 (images of 60th min and 75th min of observation). Thus, the results of quantitative colocalization analysis of proteins SubB and Rd have proved similar compartmentalization of these proteins from 30th to 60th min of observation; however, transfer of SubB to another non-reachable to Rd compartment is observed possibly from 60th to 75th min.

The ability of T-domain was recently shown to interact with COPI complex (Coatomer protein I) [31], which is responsible for retrograde vesicular transport, predominantly between Golgi apparatus and endoplasmic reticulum. According to the existing data, sites of high COPI concentration were found in compartments of early endosomes [32], role of which in early endosomes functioning is not fully understood. It has been known, however, that elimination of COPI leads to disorder in formation of early endosomes [33] and their sorting [34]. Possibly, DT T-domain throughout interaction with COPI is able to influence on toxin-contained endosomes maturation or even change their intracellular transport pathway. Other identified feature of T-domain is its ability to form proton channels $[16,35]$. T-domain DT throughout formation of proton channel is able to slow down acidification of endosomal lumen, that may slow down the process of DT-contained endosomes maturation. Influence of T-domain on the intracellular DT transport may be necessary for slowing down the internalized toxin-receptor com- 


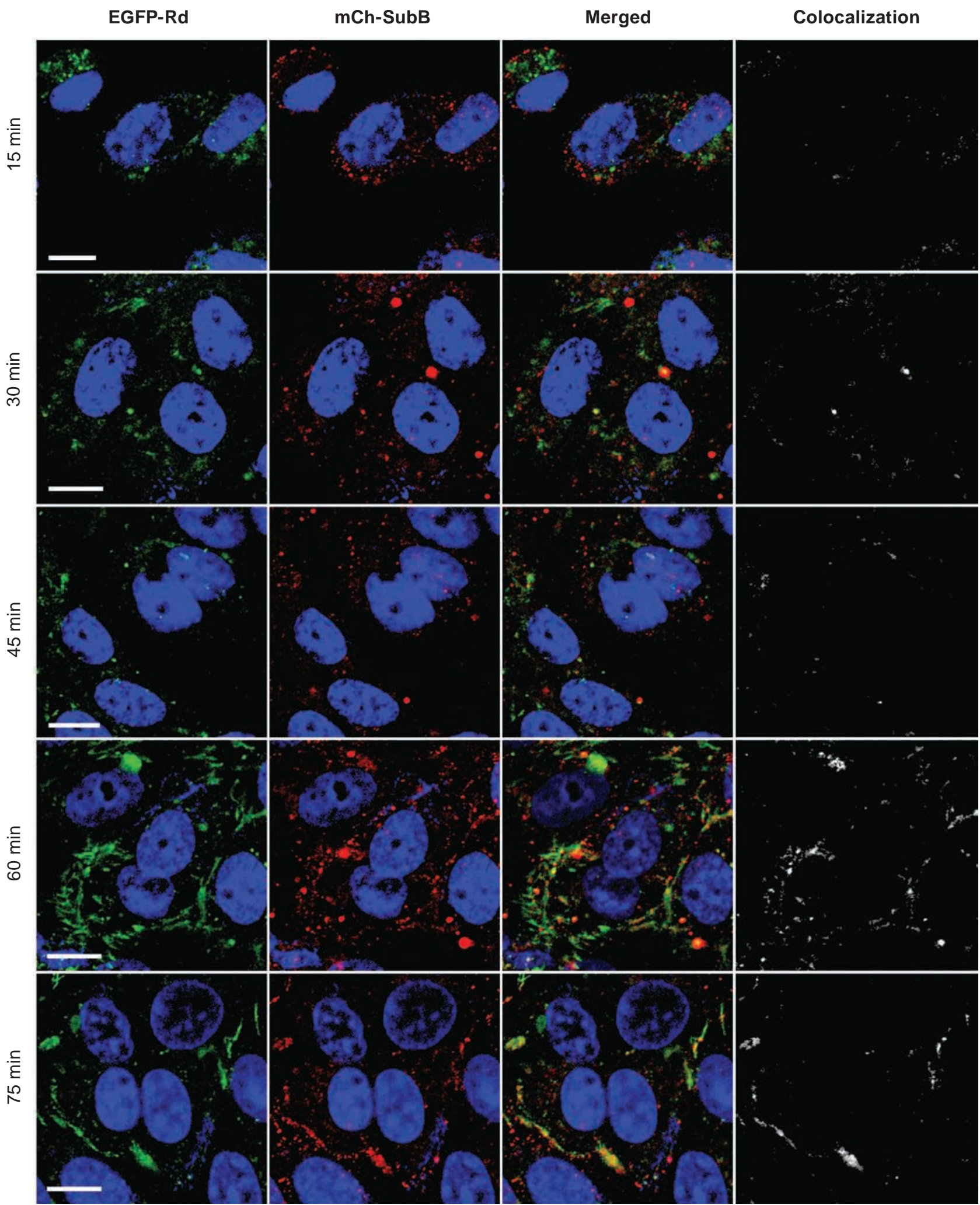

Fig. 4. Confocal images of Vero cells, incubated with fluorescent DT derivates-EGFP-Rd (pseudocolored as green) and $m$ Ch-SubB (pseudocolored as red) during 15, 30, 45, 60 and 75 min, correspondingly. Cells nuclei stained with Hoechst 33342 were shown on the pictures by blue colour. Colocalization has been calculated with FIJI software. Scale bar on the pictures corresponds to $10 \mu \mathrm{m}$ 

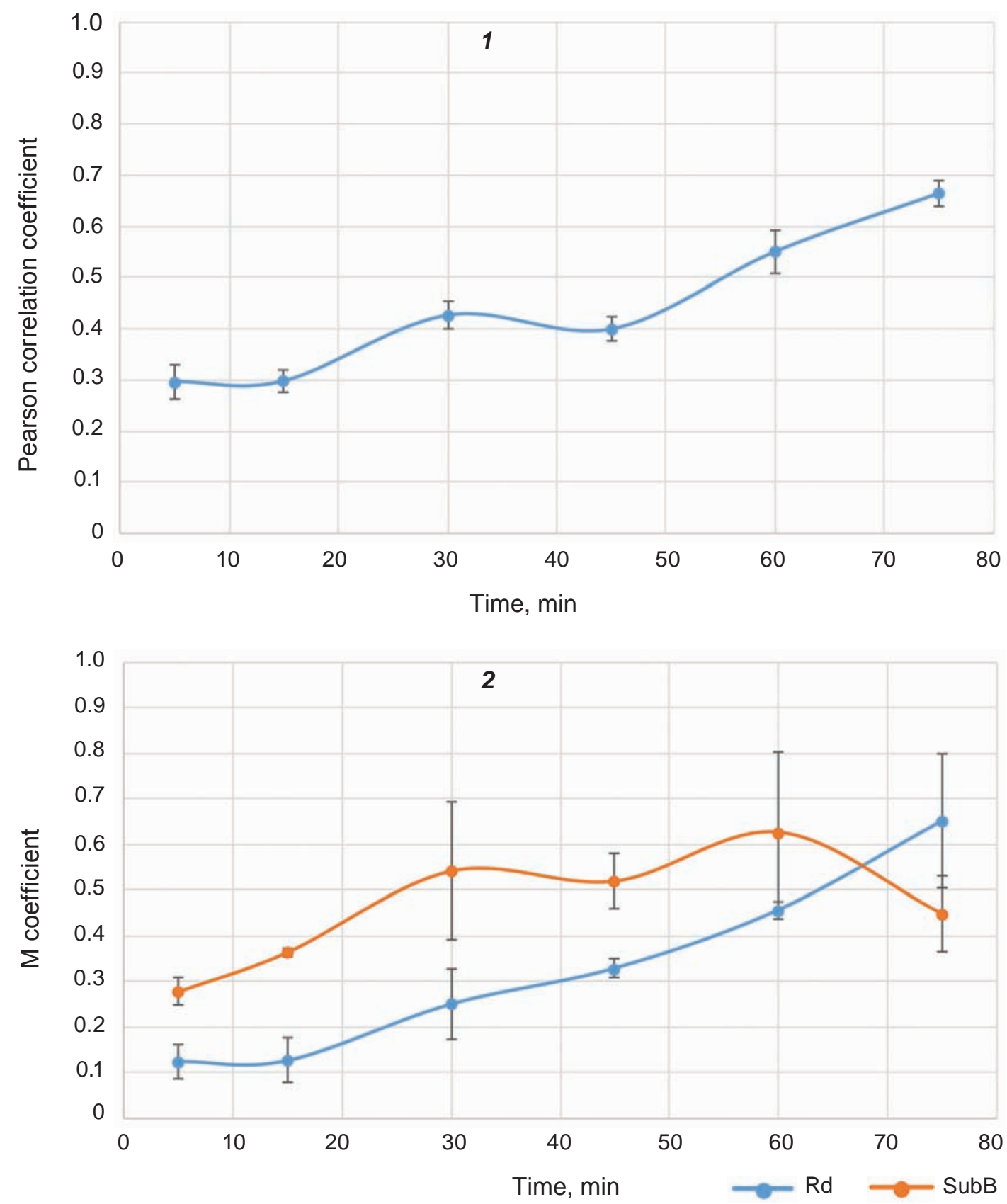

Fig. 5. Graphs of Pearson correlation coefficient (1) and $M_{1}$ and $M_{2}$ Manders coefficients dependencies on the incubation time, which show colocalization between Rd and SubB DT from 5th to 75th min of observation. Coefficient $M_{2}$, pointed as $R d$, shows a part of protein EGFP-Rd, colocalized $m C h-S u b B$, and $M_{1}$, pointed as

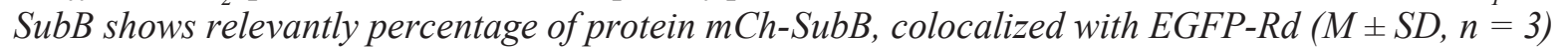

plexes transportation into cell via endosomes, that may promote more effective transport of DT C-domain into cell cytosol.

Consequently, effect of T-domain on vesicular transportation of diphtheria toxin, that may be associated with the ability of T-domain to interact with COPI proteins and/or its channel-formation activity has been shown in this work. According to the re- ceived data, velocity of intracellular transport of Rdomain and subunit B differed, and subunit B, possibly, was transported into unreachable for R-domain compartments. The shown in this work feature of T-domain DT, in our opinion, increases effectiveness of C-domain DT transportation into cell cytosol, that promotes cytotoxic activity of diphtheria toxin. 


\section{РОЛЬ Т-ДОМЕНУ \\ ДИФТЕРІЙНОГО ТОКСИНУ \\ У ВНУТРІШНЬОКЛІТИННОМУ \\ ТРАНСПОРТУВАННІ \\ ТОКСИНВМІСНИХ ВЕЗИКУЛ}

А. Ю. Лабиниев, Д. В. Колибо,

С. С. Юрченко, А. А. Кабернюк,

Н. В. Короткевич, С. В. Комісаренко

Інститут біохімії ім. О. В. Палладіна

НАН України, Кїв;

e-mail: lab.andrey@gmail.com

Субодиниця В дифтерійного токсину (ДТ), яка складається із двох доменів, $\mathrm{R}-\mathrm{pe}-$ цепторного та T - трансмембранного, відіграє важливу роль у зв'язуванні токсину з рецептором на клітинах-мішенях та у транспортуванні каталітичної субодиниці А до цитозолю. Рекомбінантні аналоги субодиниці В $є$ перспективними представниками унікального класу транспортувальних протеїнів, які здатні забезпечити доставку біологічно активних молекул до цитозолю клітин. Створення таких конструкцій вимагає з'ясування ролі кожного із фрагментів ДТ у транспортуванні комплексу рецептор-токсин.

У роботі досліджували роль Т-домену у внутрішньоклітинному транспортуванні рекомбінантних фрагментів ДТ. Для цього порівнювали особливості внутрішньоклітинного транспортування R-домену та субодиниці B, яка містить в собі як R-, так і Т-домен. Рекомбінантні фрагменти ДТ мітили флуоресцентними протеїнами, що дозволило використовувати в дослідженні техніку колокалізації. Методом конфокальної мікроскопії встановлено відмінності у транспортуванні рекомбінантних похідних ДТ у клітинах лінії Vero. Показано, що R-домен швидше потрапляє до тубулярних компартментів клітини, ніж субодиниця В. Аналіз колокалізації R-домену та субодиниці В підтверджує майже лінійне іï зростання за коефіцієнтом Пірсона (РСC) у разі збільшення часу інкубації. Проте відсоток субодиниці В, колокалізованої 3 R-доменом, визначений за коефіцієнтом Мандерса $\left(\mathrm{M}_{1}\right)$, зростає нелінійно, що може свідчити про здатність субодиниці В потрапляти до певних компартментів клітини, недоступних для R-домену. Роль Т-домену у внутрішньоклітинному транспортуванні та компартменталізації токсину, вірогідно, пов'язана 3 його здатністю до формування протонних каналів та взаємодії з комплексом протеїнів цитоплазми СОР.

К л ючов і слов а: дифтерійний токсин, Т-домен дифтерійного токсину, ендоцито3, флуоресцентні протеїни, конфокальна мікроскопія, внутрішньоклітинне транспортування.

\section{РОЛЬ Т-ДОМЕНА ДИФТЕРИЙНОГО ТОКСИНА ВО ВНУТРИКЛЕТОЧНОМ ТРАНСПОРТЕ ТОКСИНСОДЕРЖАЩИХ ВЕЗИКУЛ}

\author{
А. Ю. Лабыниев, Д. В. Колибо, \\ Е. С. Юрченко, А. А. Кабернюк, \\ Н. В. Короткевич, С. В. Комисаренко
}
Институт биохимии им. А. В. Палладина НАН Украины, Киев; e-mail: lab.andrey@gmail.com

Субъединица В дифтерийного токсина (ДТ), которая состоит из двух доменов, $\mathrm{R}-\mathrm{pe}-$ цепторного и $\mathrm{T}$ - трансмембранного, играет важную роль в связывании токсина с рецептором на клетках-мишенях и в транспорте каталитической субъединицы А в цитозоль. Рекомбинантные аналоги субъединицы В являются перспективными представителями уникального класса транспортных протеинов, которые способны обеспечить доставку биологически активных молекул в цитозоль клеток. Создание таких конструкций требует определения роли каждого из фрагментов ДТ в транспортировании поглощенного комплекса рецептор-токсин.

В работе исследовали роль Т-домена во внутриклеточном транспорте рекомбинантных фрагментов ДТ. Для этого сравнивали особенности внутриклеточного транспортирования $\mathrm{R}$-домена и субъединицы B, которая содержала как R-, так и Т-домен ДТ. Рекомбинантные фрагменты ДТ метили флуоресцентными протеинами, что позволило использовать в исследовании технику колокализации. Методом конфокальной микроскопии показаны отличия в транспортировании рекомбинантных производных ДТ в клетках линии Vero. Показано, что $\mathrm{R}$-домен быстрее, чем субъединица $\mathrm{B}$, попадает в тубулярные компартменты клетки. Анализ колокализации R-домена и субъединицы В под- 
тверждает почти линейный ее рост согласно с коэффициентом Пирсона (РСС) при увеличении времени инкубации. Однако процент субъединицы B, которая колокализирована с R-доменом, определенный по коэффициенту Мандерса $\left(\mathrm{M}_{1}\right)$, рос нелинейно, что может свидетельствовать о способности субъединицы В попадать в определенные компартменты клетки, недоступные для R-домена. Роль T-домена во внутриклеточном транспорте и компартментализации токсина, вероятно, связана с его способностью к формированию протонных каналов и взаимодействию с комплексом протеинов цитоплазмы СОРІ.

Ключевы е с лова: дифтерийный токсин, Т-домен дифтерийного токсина, эндоцитоз, флуоресцентные протеины, конфокальная микроскопия, внутриклеточный транспорт.

1. Romaniuk S. I., Kolibo D. V., Komisarenko S. V. // Rus. J. Bioorg. Chem. - 2012. - 38, N 6. P. 639-652.

2. Kolibo D. V., Labyntsev A. J., Romaniuk S. I. et al. // Biotechnol. Acta. -2013. - 6, N 4. - P. 43-62.

3. Gordon V., Klimpel K., Arora N. et al. // Infect. Immun. - 1995. - 63, N 1. - P. 82-87.

4. Gordon V. M., Rehemtulla A., Leppla S. H. // Infect. Immun. - 1997. - 65, N 8. - P. 3370-3375.

5. Sucic J. F., Moehring J. M., Inocencio N. M. et al. // Biochem. J. - 1999. - 339 ( Pt 3). - P. 639-647.

6. Gordon V. M., Leppla S. H. // Infect. Immun. 1994. - 62, N 2. - P. 333-340.

7. Tsuneoka M., Nakayama K., Hatsuzawa K. et al. // J. Biol. Chem. - 1993. - 268, N 35. - P. 2646126465.

8. Ratts R., Zeng H., Berg E. A. et al. // J. Cell Biol. - 2003. - 160, N 7. - P. 1139-1150.

9. Choe S., Bennett M. J., Fujii G. et al. // Nature.1992. - 357, N 6375. - P. 216-222.

10. Rolf J. M., Gaudin H. M., Eidels L. // J. Biol. Chem. - 1990. - 265, N 13. - P. 7331-7337.

11. Higashiyama S., Abraham J. A., Miller J. et al. // Science (New York, N.Y.). - 1991. - 251, N 4996. - P. 936-939.

12. Higashiyama S., Lau K., Besner G. E. et al. // J. Biol. Chem. - 1992. - 267, N 9. - P. 6205-6212.

13. Naglich J. G., Metherall J. E., Russell D. W. et al. // Cell. - 1992. - 69, N 6. - P. 1051-1061.

14. Здановский А. Г., Здановская М. В., Янковский Н. К. // Молекулярная генетика, микробиология и вирусология. - 1988. - 12. C. 3-10.
15. Morris R. E., Gerstein A.S., Bonventre P. F. et al. // Infec. Immun. - 1985. - 50, N 3. - P. 721-727.

16. Senzel L., Huynh P. D., Jakes K. S. et al. // J. Gen. Physiol. - 1998. - 112, N 3. - P. 317-324.

17. Oh K. J., Senzel L., Collier R. J. et al. // Proc. Natl Acad. Sci. USA. - 1999. - 96, N 15. - P. 84678470.

18. Lanzrein M., Sand O., Olsnes S. // EMBO J. 1996. - 15, N 4. - P. 725-734.

19. Takahashi T., Umata T., Mekada E. // Biochem. Biophys. Res. Commun. - 2001. - 281, N 3. P. 690-696.

20. Quertenmont P., Wolff C., Wattiez R. et al. // Biochemistry. - 1999. - 38, N 2. - P. 660-666.

21. Lory S., Carroll S. F., Collier R. J. // J. Biol. Chem. - 1980. - 255, N 24. - P. 12016-12019.

22. Ren J., Kachel K., Kim H. et al. // Science (New York, N.Y.). - 1999. - 284, N 5416. - P. 955-957.

23. Hammond K., Caputo G. A., London E. /I Biochemistry. - 2002. - 41, N 9. - P. 3243-3253.

24. Wang Y., Kachel K., Pablo L. et al. // Biochemistry. - 1997. - 36, N 51. - P. 16300-16308.

25. Кабернюк А.А., Лабинцев А.Ю., Колибо Д.В. та ін. // Укр. біохім. журн. - 2009. - 81, № 1. C. 67-77.

26. Schägger H., von Jagow G. // Anal. Biochem. 1987. - 166, N 2. - P. 368-379.

27. Yasumura Y., Kawakia Y. // Nippon Rinsho. 1963. - 21. - P. 1209-1210.

28. Schindelin J., Arganda-Carreras I., Frise E. et al. // Nat. Methods. - 2012. - 9, N 7. - P. 676-682.

29. Bolte S., Cordelières F. P. // J. Microsc. - 2006. 224, N 3. - P. 213-232.

30. Dunn K. W., Kamocka M. M., McDonald J. H. // Am. J. Physiol. Cell Physiol. - 2011. - 300, N 4. - P. C723-742.

31. Trujillo C., Taylor-Parker J., Harrison R. et al. // Mol. Microbiol. - 2010. - 76, N 4. - P. 1010-1019.

32. Aniento F., Gu F., Parton R. G. et al. // J. Cell Biol. - 1996. - 133, N 1. - P. 29-41.

33. Razi M., Chan E. Y. W., Tooze S. A. // J. Cell Biol. - 2009. - 185, N 2. - P. 305-321.

34. Styers M. L., O'Connor A. K., Grabski R. et al. // Am. J. Physiol. Cell Physiol. - 2008. - 294, N 6. - P. C1485-1498.

35. Kurnikov I. V., Kyrychenko A., Flores-Canales J. C. et al. // J. Mol. Biol. - 2013. - 425, N 15. - P. 2752-2764.

Отримано 24.10.2013 